\title{
京津冀地区物种多样性保护优先区识别研究
}

\author{
邢韶华 ${ }^{1}$, 周 金金 ${ }^{1,2}$, 刘云强 ${ }^{3}$, 袁 秀 ${ }^{4, *}$ \\ 1 北京林业大学生态与自然保护学院, 北京 100083 \\ 2 拉萨市曲水县聂当乡人民政府，拉萨 850600 \\ 3 辽宁农业职业技术学院园林系,营口 115009 \\ 4 中国科学院科技战略咨询研究院, 北京 100190
}

\begin{abstract}
摘要: 着力扩大环境容量和生态空间,加强跨区环境保护合作, 是落实京津冀一体化协同发展国家战略的重要内容。摸清京津 冀地区的生物多样性分布格局,可为国家公园布局、生态环境保护工程的实施提供依据。根据“自然保护区生物多样性保护价 值评估技术规程 ( LY/T 2649-2016)”, 基于京津冀地区自然保护区的综合科学考察报告,评估了京津冀地区典型自然保护区 的物种多样性保护价值,并以其为因变量, 以自然保护区的综合地形地貌为自变量, 构建多元回归模型, 同时以自然保护区的平 均面积为基准,利用 ArcGIS 的创建 “渔网”功能,将京津冀地区划分为 1638 个网格单元,利用构建的多元回归模型评估了这些 网格单元的保护价值。结果表明:京津冀地区国家级自然保护区的保护价值平均得分为 204 分,比参评的全部 35 个自然保护 区的平均分高 40 分; 在省级自然保护区中也存在一些得分较高的自然保护区,如,唐海湿地自然保护区和河北南大港自然保护 区, 且超过了参评国家级自然保护区保护价值得分的平均值。京津冀地区的物种多样性保护优先区总面积为 $36791.35 \mathrm{~km}^{2}$, 占 京津冀地区总面积的 $16.94 \%$, 其中一级保护优先区面积 $4611.57 \mathrm{~km}^{2}$, 二级保护优先区面积 $16045.79 \mathrm{~km}^{2}$,三级保护优先区面积 $16133.98 \mathrm{~km}^{2}$ 。这些区域主要分布在河北省和北京市的北部地区, 区域内绝大部分以森林植被和灌丛植被为主。建议在未来 的国家公园布局、生态环境保护工程布局中重点考虑这些地区。
\end{abstract}

关键词:京津冀地区;保护优先区;生物多样性;自然保护区

\section{Priority areas identification for species diversity protection in Beijing-Tianjin- Hebei Region}

\author{
XING Shaohua ${ }^{1}$, ZHOU Xin ${ }^{1,2}$, LIU Yunqiang ${ }^{3}$, YUAN Xiu ${ }^{4, *}$ \\ 1 School of Ecology and Nature Conservation, Beijing Forestry University, Beijing 100083, China \\ 2 People's Government of Niedang Town, Qushui County, Lhasa 850600, China \\ 3 Department of Landscape, Liaoning Agricultural Technical College, Yingkou 115009, China \\ 4 Institutes of Science and Development, Chinese Academy of Sciences, Beijing 100190, China
}

\begin{abstract}
The integration and coordinated development of Beijing, Tianjin and Hebei region (BTHr) is a national strategy. The primary tasks of this strategy are to expand ecological space and environmental capacity, and strengthen the crossregional cooperation of ecological environment protection in the BTHr. Clarifying the distribution of biodiversity in the BTHr is the premise and foundation for the implementation of ecological environmental protection projects and for the allocation of national parks. We assessed the biodiversity conservation value of nature reserves in the BTHr. The assessment used the forestry industry standard “Technical Regulation for Assessing Biodiversity Conservation Value of Nature Reserves (LY/T 2649-2016)" and was based on scientific investigations of nature reserves in the BTHr, In addition, we constructed a multivariate regression model in which the biodiversity conservation value of the nature reserves was the dependent variable and the comprehensive landforms of the nature reserves were the independent variables. Based on the average area of the nature reserves, we divided the BTHr into 1638 grid cells using the "fishing net" function of ArcGIS. The biodiversity
\end{abstract}

基金项目:中央高校基本科研业务费专项资金项目(2015ZCQ-BH-02); 国家重点研发计划项目(2017YFC0505802-3)

收稿日期: 2020-02-13; 修订日期: 2020-10-14

*通讯作者 Corresponding author.E-mail: yuanxiu@ casisd.cn 
conservation value of each grid cell was evaluated by using the multivariate regression model. The average conservation value of the national nature reserves in the BTHr was 204 points, which was 40 points higher than the average conservation value of the total 35 nature reserves. Some provincial nature reserves, such as Tanghai wetland nature reserve and Nandagang nature reserve, also had comparatively high conservation values, which exceeded the average conservation value of the national nature reserves. Biodiversity conservation priority areas were selected according to the conservation value of each grid in the BTHr. The total area of biodiversity conservation priority areas was $36791.35 \mathrm{~km}^{2}$, accounting for $16.94 \%$ of the total area of the BTHr. Conservation priorities were divided into three levels: the first-level conservation priority area $\left(4611.57 \mathrm{~km}^{2}\right)$, second-level conservation priority area $\left(16045.79 \mathrm{~km}^{2}\right)$, and third-level conservation priority area $\left(16133.98 \mathrm{~km}^{2}\right)$. These conservation priority areas are mainly distributed in the north of Hebei Province and Beijing. Most of them are dominated by forest vegetation and shrub vegetation. We suggest that these areas should be considered in the layout of national parks and ecological and environmental protection projects.

Key Words : Beijing-Tianji-Hebei region(BTHr) ; conservation priority areas; biodiversity; nature reserve

生物多样性的丧失早已引起了国际社会的普遍关注,开展生物多样性保护是一项长期艰巨的任务。生物 多样性保护工作者从基因、物种到群落、甚至生态系统的各个水平,从自然保护区、区域地带到全球的各个尺 度开展了多种形式的研究与实践。Myers 在分析热带雨林受威胁程度的基础上,首先提出了热点地区的概 念 ${ }^{[1]}$, 并根据物种特有程度和受威胁程度提出了全球范围内的 25 个生物多样性热点地区。此后生物多样性 热点地区的评估在不同尺度上广泛展开, 评估指标、评估方法也更加多样。总体上来讲, 生物多样性热点地区 的评估主要基于物种多样性和生态系统的多样性,如,李迪强等将鸟类作为生物多样性丰富度的指示,将森林 分布作为生态系统的指示, 评价了尤溪县生物多样性的优先保护地区 ${ }^{[2]}$; 高玉平通过分析上海市植物及脊椎 动物的分布热点, 选择出上海市物种多样性的优先保护地区 ${ }^{[3]}$ 。在生态系统多样性层面, 除了选用最多的植 被外, 有研究者又选择了一些其他的指标, 如特殊的气候地理与土壤特征、特殊生境等评价指标, 进行优先保 护地区的评价 ${ }^{[4]}$ 。生物多样性的优先保护地区 (热点地区) 的形成是该地区的气候、地形地貌以及人为活动 等多种因素综合作用的结果。在一个气候条件相对一致的区域里,地形地貌是影响物种分布的重要因素。从 全球范围来看,生物多样性高的热点地区通常分布在地形地貌复杂、地质条件多样的区域 ${ }^{[5-7]}$; 并且, 地形复 杂区域通常有更多特有种、狭域种和受威胁种, 具有高的保护价值 ${ }^{[8]}$ 。地形要素是最基本的自然地形单元, 影响着地表物质迁移与能量转换、地表过程以及景观格局等 ${ }^{[9]}$ 。地形是水热条件外的一个非常重要的、影响 生物多样性分布格局的因素。有研究表明,至少在陆地生态系统, 地形异质性可以显著解释气候的剩余变异 (residual variations) ${ }^{[10]}$ 。地形因子的作用在于影响物质和能量的再分配 ${ }^{[11]}$, 地形是多种环境因子的复合, 水 分、温度和土壤养分的变化集中体现在地形梯度的变化上 ${ }^{[12]}$ 。京津冀地区作为 “我国经济最具活力、开放程 度最高、创新能力最强、吸纳外来人口最多的地区” ${ }^{[13]}$ 之一, 同时也 “面临水土资源短缺和生态环境压力加 大” ${ }^{[13]}$ 等问题，因此更应该根据《生态文明体制改革总体方案》的要求，“健全国土空间用途管制制度” ${ }^{[14]}$, “将用途管制扩大到所有自然生态空间,划定并严守生态红线,严禁任意改变用途, 防止不合理开发建设活动 对生态红线的破坏。” ${ }^{[14]}$ 。本文拟通过建立典型自然保护区地形异质性与生物多样性关系模型, 对京津冀地 区物种多样性保护优先区进行预测与评估, 以期为京津冀地区深化生态文明体制改革、国家公园布局提供技 术参考。

\section{1 研究区域概况}

京津冀地区地处华北平原北部,包括北京市、天津市以及河北省 (北纬 $36^{\circ} 03^{\prime}-42^{\circ} 40^{\prime}$, 东经 $113^{\circ} 27^{\prime}-$ $119^{\circ} 50^{\prime}$ ), 总面积约 21.72 万 $\mathrm{km}^{2}$, 北靠燕山山脉, 南面华北平原, 西倚太行山脉, 东临渤海, 东部和南部地形较 为平坦, 属于华北平原, 是典型的农业区, 北部和西北部地势相对较高 ${ }^{[15]}$ 。地形由西北向的燕山-太行山山系 构造向东南逐步过渡为平原, 呈现出西北高东南低的地形特点 ${ }^{[16]}$ 。最高峰为位于河北省的小五台山, 海拔 
$2882 \mathrm{~m}$ 。除西北坝上高原、围场山地、张家口、宣化河谷盆地、蔚县盆地、丰宁山地属温带大陆性季风气候区 外, 其余皆为暖温带大陆性季风气候区, 年平均气温 $0-13^{\circ} \mathrm{C}$, 年平均降水量为 $300-800 \mathrm{~mm}^{[17]}$ 。

京津冀地区的地带性植被是以栋类、杨华林等为主的暖温带落叶阔叶林,间或有温性松林分布; 山地高海 拔地区和河北省的北部地区分布有山地草甸,亦或是草甸草原。东南部平原区是主要农作区,以小麦、玉米等 农作物为主, 自然植被很少。地带性土壤主要有棕壤和褐土, 此外有少量的盐碱土和沼泽土。自山地、山麓至 滨海大致是:棕壤(棕色森林土)-淋溶褐土-潮褐土-潮土和褐土化潮土-滨海盐碱土。

\section{2 材料与方法}

\section{1 数据来源}

(1) 自然保护区野生动植物信息数据资料

在研究区域内选择了野生动植物信息数据齐全的 35 个自然保护区 (表 1), 其中属于森林生态系统类型 的有 24 个, 内陆湿地类型的有 7 个,草原草甸类型的有 4 个。野生动植物信息数据包括野生动植物种类及被 IUCN 物种红色名录、生物多样性红色名录、中国物种红色名录、国家重点保护野生动植物名录的收录情况。 数据来源于公开出版的自然保护区综合科学考察报告 ${ }^{[18-26]}$ 、学位论文 ${ }^{[27-29]}$ 、专著 ${ }^{[30-33]}$ 等, 或者是自然保护区 的内部资料。

(2) 植被分布数据

来源于 1:1000000 的矢量化中国植被图 ${ }^{[34]}$ 。

(3) 地形高程数据

来源于 91 卫图助手下载的分辨率为 $60 \mathrm{~m}$ 的 DEM 数据。

(4) 行政区区划、居民点等其他数据

京津冀地区行政区边界、居民点位置信息来源于我国行政区划图 ${ }^{[35]}$ 。

2.2 研究方法

2.2.1 自然保护区物种多样性保护价值量化

根据林业行业相关技术标准 ${ }^{[36]}$, 对 35 个自然保护区综合科学考察报告中的维管束植物、陆地脊椎动物 与鸟类名录进行整理, 将动植物的濒危性和保护等级作为主要参考指标, 从中篮选出 IUCN 物种红色名录、生 物多样性红色名录、中国物种红色名录中近危种及以上的动植物物种, 国家二级及以上的重点保护动植物物 种 (除国家重点保护野生动植物名录以外的名录, 以下统称为其他名录), 共计 218 种。按保护等级为这些动 植物物种赋分: 国家一级重点保护物种、其他名录中极危种赋值为 8 分; 国家二级保护物种、其他名录中濒危 种赋值为 4 分; 其他名录中易危种赋值为 2 分; 其他名录中近危种和无危种赋值为 1 分 ${ }^{[37-38]}$ 。一个物种在不 同名录中保护级别不同时, 按照最高级别赋分的方式。在此基础上算出每个自然保护区的物种多样性保护价 值得分, 记作保护价值, 并以此作为判断生物多样性热点分布的指引依据。

\subsection{2 物种多样性保护优先区预测}

1) 以这 24 个森林生态系统类型自然保护区的平均面积为参考, 利用 ArcGIS 的创建渔网 (fishnet) 功能, 将京津冀地区划分为 $12 \mathrm{~km} \times 12 \mathrm{~km}$ 大小的格网, 共计 1651 个网格单元(含不完整网格单元)。

2 ) 利用 GIS 软件将京津冀地区的 DEM 数据、植被分布数据与 1651 个网格单元(含不完整网格单元) 进 行叠加,计算出每个网格单元内不同海拔段 ( 0 - $200 \mathrm{~m}, 201-400 \mathrm{~m}, 401-600 \mathrm{~m}, \cdots,>2601 \mathrm{~m})$ 、不同植被类 型 (参考《中国植被图集》的分类)、坡度 $\left(\right.$ 平坡 $\left(0^{\circ}-5^{\circ}\right)$ 、缓坡 $\left(5^{\circ}-15^{\circ}\right)$ 、斜坡 $\left(15^{\circ}-25^{\circ}\right)$ 、陡坡 $\left(25^{\circ}-35^{\circ}\right)$ 、 急坡 $\left(35^{\circ}-45^{\circ}\right)$ 和险坡 $\left(\right.$ 大于 $\left.45^{\circ}\right)$ ) 、坡向 (平地、阴坡 $(\mathrm{N} 、 \mathrm{NW})$ 、阳坡 $(\mathrm{S} 、 \mathrm{SW})$ 、半阴坡 $(\mathrm{W} 、 \mathrm{NE})$ 、半阳坡 $(\mathrm{SE}$ 、 E) ) 等因子的面积比例以及最高海拔、最低海拔和海拔差等, 共计 32 个因子。

4) 利用 SPSS 软件对 2) 中得到的各地形因子、植被分布因子等 32 个因子进行主成分分析 (PCA) 降维,获 得影响自然保护区保护价值的主成分变量。 
5) 提取 24 个森林生态系统类型自然保护区所对应的单元网格的主要成分变量,利用 SPSS 软件将 24 个 自然保护区的保护价值与对应的单元网格的主成分变量进行多元回归分析, 确定回归系数及回归方程, 判断 其显著性。将 24 个自然保护区涵盖范围外的网格单元的主成分变量代人回归方程, 从而获得每个网格单元 的预测值, 预测值即为每一个网格单元的保护价值。

多元线性回归模型的建立:

假设某一因变量 $y$ 受 $k$ 个自变量 $x_{1}, x_{2}, \cdots, x_{k}$ 的影响,其观测值为 $\left(y, x_{1}, x_{2}, \cdots, x_{k}\right)$,多元线性回归模型 的结构为:

$$
y=\beta_{0}+\beta_{1} x_{1}+\beta_{2} x_{2}+, \cdots,+\beta_{k} x_{k}+\varepsilon
$$

式中, $\beta_{0}, \beta_{1}, \cdots, \beta_{k}$ 为待定参数, $\varepsilon$ 为常量

如果 $b_{0}, b_{1}, \cdots, b_{k}$ 分别是 $\beta_{0}, \beta_{1}, \beta_{2}, \cdots, \beta_{k}$ 的拟合值, 则回归方程为:

$$
\gamma^{\prime}=b_{0}+b_{1} x_{1}+b_{2} x_{2}+, \cdots,+b_{k} x_{k}
$$

式中, $b_{0}$ 为常数, $b_{1}, b_{2}, \cdots, b_{k}$ 为偏回归系数。

该回归模型中, $y$ 即为观测值, $x_{1}, x_{2}, \cdots, x_{k}$ 即为生成主成分变量, $\beta_{0}, \beta_{1}, \cdots, \beta_{k}$, 即为系数矩阵中的常 数, $\varepsilon$ 为残差统计矩阵中的残差, $\gamma^{\prime}$ 即为预测值。

6) 将网格单元预测值导人 ArcGIS 中对应网格单元, 即该网格的保护价值, 形成京津冀地区的物种多样性 保护价值分布图,最后根据保护价值的分布情况确定保护优先区。

\section{3 结果与分析}

\section{1 自然保护区物种多样性保护价值情况}

通过对京津冀地区 35 个自然保护区的物种多样性保护价值进行量化评分, 结果见表 1 。

由表 1 可见,国家级自然保护区普遍得分较高,平均得分为 204 ,比参与评分的 35 个自然保护区平均分 高出 40 分。在国家级自然保护区中河北衡水湖自然保护区的保护价值得分最高, 为 306 , 也是唯一一个得分 超过 300 分的自然保护区,其次是河北驼梁自然保护区、塞罕坝自然保护区,得分分别为 288 、266。得分较低 的国家级自然保护区分别是北京松山自然保护区、北京百花山和天津八仙山自然保护区、得分分别为 152 、 143 和 139。在省级自然保护区中也存在一些得分较高的自然保护区,如唐海湿地自然保护区和河北南大港 自然保护区,这两个湿地类型的自然保护区的保护价值得分都在 200 以上, 且超过了参评国家级自然保护区 保护价值得分的平均值, 因此应引起注意。

从不同类型自然保护区的保护价值的得分情况看,森林类型的自然保护区得分最高的为河北驼梁自然保 护区,得分为 288 ; 得分最低的为河北兴隆六里坪狝猴省级自然保护区,得分仅为 40 。湿地类型的自然保护区 得分最高的为河北衡水湖国家级自然保护区，得分为 306 ,得分最低的为河北白洋淀湿地省级自然保护区,得 分为 45 。草原草甸类型的自然保护区得分最高的为河北围场红松洼国家级自然保护区,得分为 243 ; 得分最 低的是河北丰宁满族滦河源省级自然保护区，得分为 112 。由此可以看出不同类型自然保护区的保护价值之 间不存在显著差异, 同一类型自然保护区的保护价值差别却很大, 尤其是森林生态系统类型自然保护区和内 陆湿地类型的自然保护区。

\section{2 物种多样性保护优先区预测及保护优先等级划分}

\subsection{1 回归模型的构建}

对 32 个环境变量因子进行主成分分析,选取特征值大于 1 的根作为主成分数量,共提取了 8 个主成分, 即 $\lambda 1=11.998 、 \lambda 2=3.593 、 \lambda 3=3.045 \cdots \cdots \lambda 8=1.053$, 分别对应的第 1 个主成分、第 2 个主成分、第 3 个主成 分……第 8 个主成分, 其方差贡献率分别为 $37.495 \% 、 11.229 \% 、 9.516 \% \cdots \cdots 3.291 \%$, 累计方差贡献率为 $80.196 \%$,见表 2。 


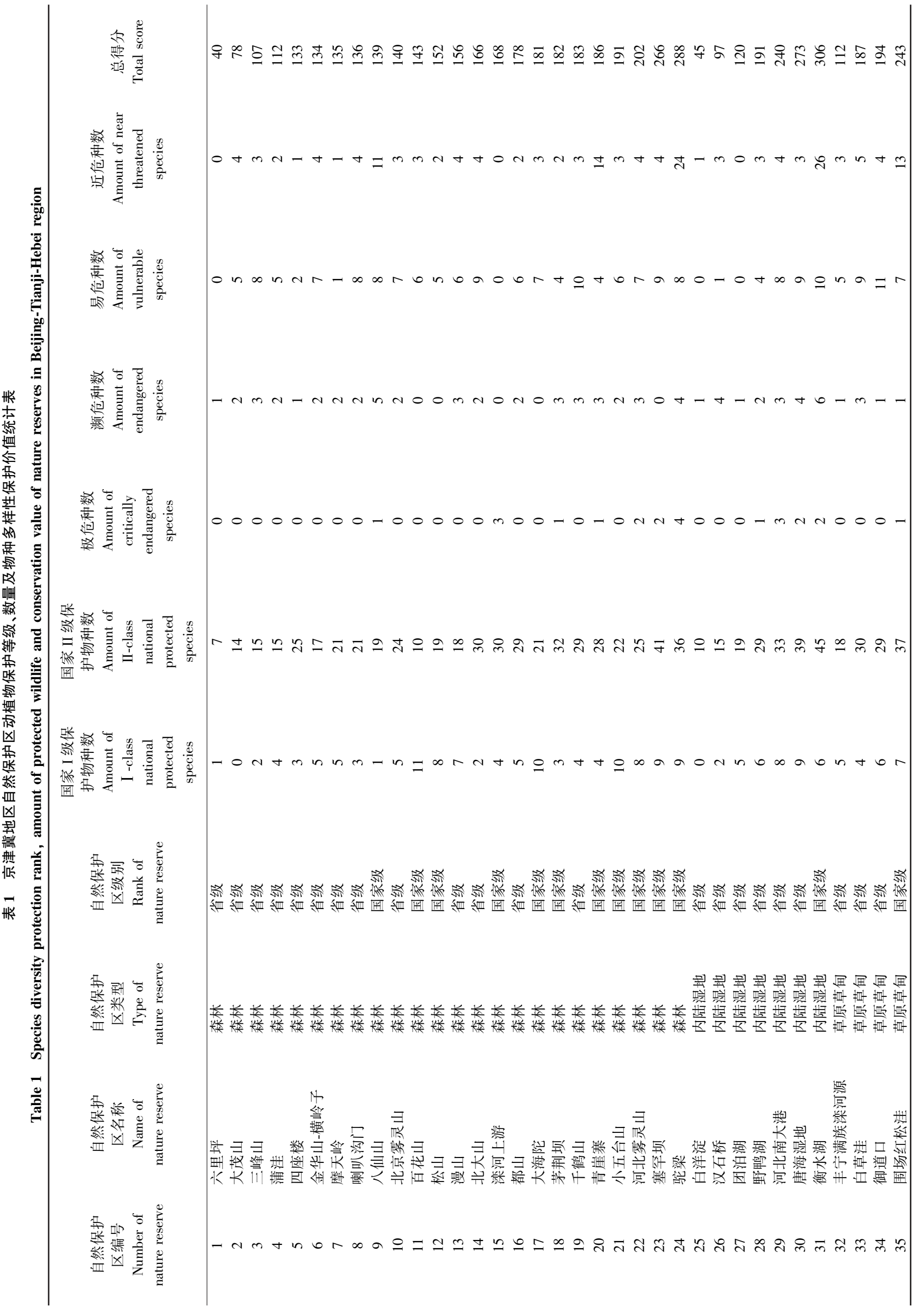


表 2 主成分分析的解释总方差

Table 2 The total variance of Principal component analysis

\begin{tabular}{cccc}
\hline $\begin{array}{c}\text { 主成分 } \\
\text { Components }\end{array}$ & $\begin{array}{c}\text { 初始特征值 } \\
\text { Initial eigenvalue }\end{array}$ & $\begin{array}{c}\text { 贡献率/\% } \\
\text { Contribution rate }\end{array}$ & $\begin{array}{c}\text { 累积贡献率/\% } \\
\text { Cumulative contribution rate }\end{array}$ \\
\hline 1 & 11.998 & 37.495 & 37.495 \\
3 & 3.593 & 11.229 & 48.724 \\
4 & 3.045 & 9.516 & 58.240 \\
5 & 2.023 & 6.321 & 64.560 \\
6 & 1.594 & 4.981 & 69.541 \\
7 & 1.288 & 4.024 & 73.565 \\
8 & 1.069 & 3.341 & 76.906 \\
\hline
\end{tabular}

利用 24 个自然保护区的保护价值和相对应的 8 个(主成分) 环境变量进行回归分析, 确定回归系数,建 立回归方程, 见公式 (3)。并通过方差分析, 对整个回归方程做显著性检验, 结果显示 $\mathrm{Sig}=0.048$, 见表 3 。说 明主成分变量与保护价值存在显著相关性,可以用这个模型来预测。

回归方程如下:

$$
\gamma^{\prime}=204.81-23.00 x_{1}+23.42 x_{2}+39.46 x_{3}-16.46 x_{4}+29.06 x_{5}-14.27 x_{6}-14.41 x_{7}-46.97 x_{8}
$$

表 3 显著性分析表

Table 3 Significant analysis table

\begin{tabular}{lcccc}
\hline & $\begin{array}{c}\text { 平方和 } \\
\text { Sum of squares }\end{array}$ & $d f$ & $\begin{array}{c}\text { 均方 } \\
\text { Mean square }\end{array}$ & Sig. \\
\hline 回归 Regression & 36903.589 & 8 & 4612.949 & 2.665 \\
残差 Residual & 25967.744 & 15 & 1731.183 & 0.048 \\
总计 Total & 62871.333 & 23 & & \\
\hline
\end{tabular}

\subsection{2 保护价值的计算}

将京津冀地区所有网格单元的主成分环境因子代人以上回归方程,计算出所有网格的保护价值,将网格 单元保护价值导人 ArcGIS 中对应网格单元, 结果如图 1 所示,图中颜色越深,说明该网格的保护价值得分越高, 即保护价值越高。

对 24 个森林类型自然保护区的保护价值得分进行 “有序样品聚类”分析 (图 2), 将 24 个自然保护区的保 护价值分为了三组,其中编号为 23,24 的自然保护区组 成一组,该组的保护价值最高; 编号为 $1,2,3,4$ 的自然 保护区组成一组,该组的保护价值最低。剩余的划为一 组, 其保护价值居中, 取这一组保护价值中的低值 (133) 作为保护优先区和非保护优先区的分界线; 取这 一组保护价值中的高值 (202) 作为一级保护优先区和 二级保护优先区的分界线; 这一组又可分为两小组, 取 保护价值较低一组的高值 (156) 作为二级保护优先区 和三级保护优先区的分界线。最终确定以 133 分、156 分、202 分 3 个值作为划分优先保护级别的临界值。 133 分以下的区域不作为保护区域, 133 分-156 分的

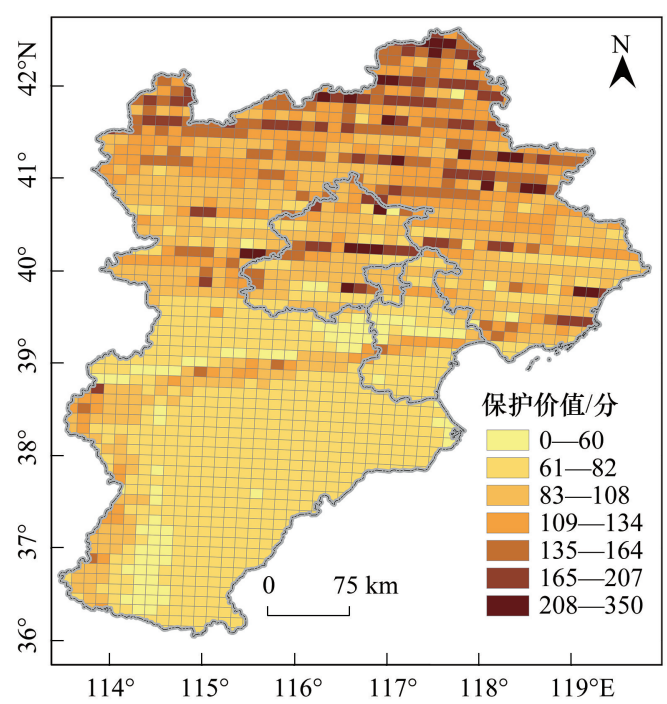

图 1 网格化的京津冀地区物种多样性保护价值分布图

Fig.1 Biodiversity conservation value distribution in latticed BTHr 
区域划分为三级保护优先区, 157 分一 202 分的区域划分为二级保护优先区,203 分以上的区域划分为一级保 护优先区。

为了增加保护优先区的精度,将预测到的物种多样性保护优先区等级分布图与京津冀地区自然植被图进 行叠加分析, 去除其中农田、水域、盐场等非自然植被,叠加分析后得到图 3。统计表明,划定的三个等级保护 优先区总面积为 $36791.35 \mathrm{~km}^{2}$, 占京津冀总面积的 16.94\%。其中,一级保护优先区总面积为 $4611.57 \mathrm{~km}^{2}$, 占 总优先区域面积的 $12.53 \%$; 二级保护优先区总面积为 $16045.79 \mathrm{~km}^{2}$, 占总优先区域面积的 $43.61 \%$; 三级保护 优先区总面积为 $16133.98 \mathrm{~km}^{2}$,占总优先区域面积的 $43.85 \%$ 。

保护优先区内分布有森林植被 $8204.47 \mathrm{~km}^{2}$, 灌丛植被 $14457.72 \mathrm{~km}^{2}$, 灌草丛植被 $3427.88 \mathrm{~km}^{2}$, 草甸、草 原、草丛等草本植被 $10701.25 \mathrm{~km}^{2}$, 分别占总面积的 $29.09 \%, 9.32 \%, 39.30 \%, 22.30 \%$ 。森林植被主要有白桦 林、蒙古栎林、华北落叶松林、油松林、山杨林等,灌丛植被主要有荆条酸東灌丛、绣线菊灌丛、虎榛子灌丛、黄 栌灌丛等, 草本植被类型较复杂, 可以分为草原、草甸和一般草地, 草原主要有羊草、丛生禾草草原、西北针茅 草原、贝加尔针茅、杂类草草原等, 草甸主要有苔草、杂类草草甸、野古草、大油芒、杂类草草甸、莋夰草草甸等。

物种多样性保护优先区共涉及京津冀地区 56 个区县, 主要有河北省北部的围场满族蒙古族自治县、丰宁 满族自治县、隆化县、赤城县、沽源县、康保县、㴒平县、平泉县、承德县、溷鹿县、张北县; 北京市的延庆区、密云 区、房山区、昌平区等。所有区、县 (市) 中围场满族蒙古族自治县内保护优先区面积最大, 约为 $5153.48 \mathrm{hm}^{2}$, 其次是丰宁满族自治县,约为 $4044.21 \mathrm{hm}^{2}$ 。

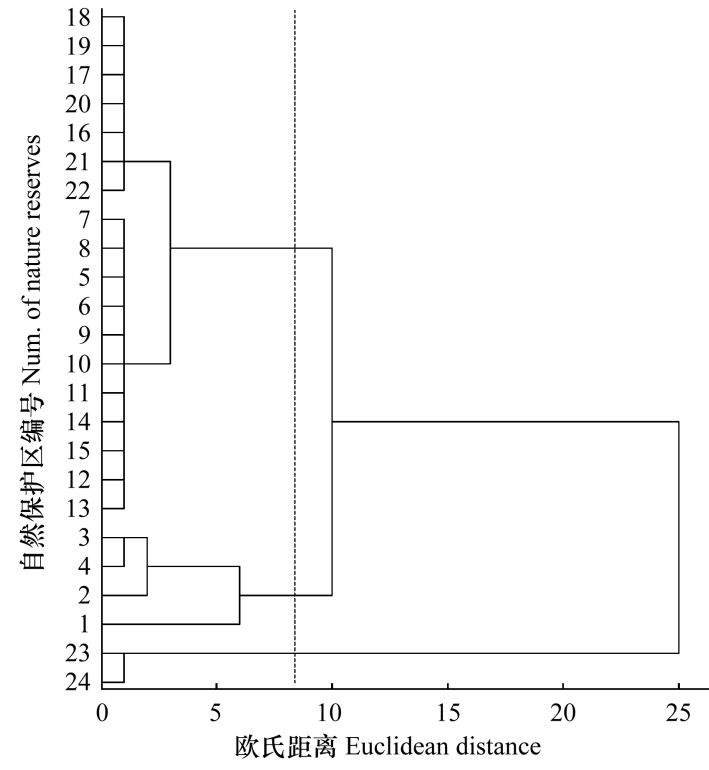

图 2 自然保护区保护价值得分聚类图

Fig.2 Distribution trend of conservation value of nature reserve

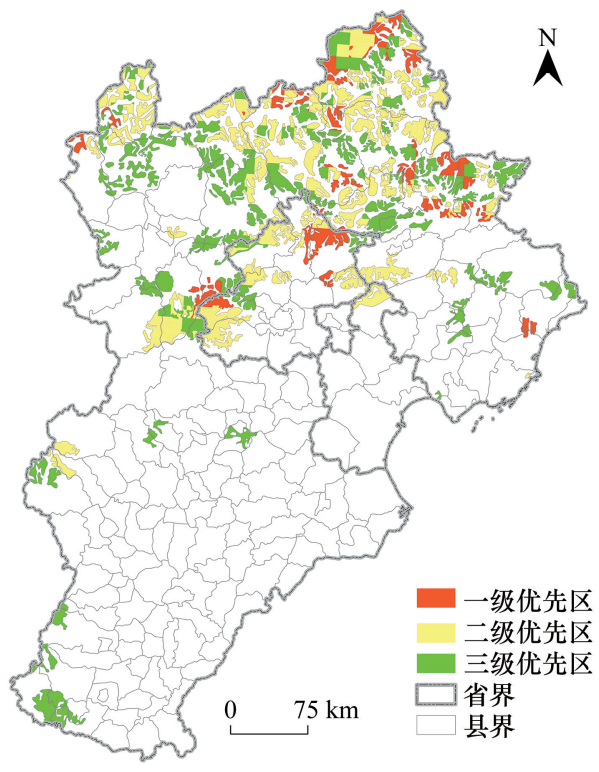

图 3 京津冀地区物种多样性保护优先区分布图

Fig.3 Priority area for biodiversity conservation in BTHr

\section{4 讨论}

(1) 以国家重点保护的、珍稀濒危的的野生动植物物种作为评价生物多样性热点区域的指标是当前研究 的重要方法。如奕晓峰等人在进行东北地区生物多样性热点区域评价和保护空缺研究时,将国家一级和二级 重点保护物种、东北地区特有物种、东北地区罕见或数量极为稀少的珍稀种类以及国际上较为关注的物种, 作 为生物多样性热点地区评价的指示物种, 并最终确定了 64 种濒危和特有动植物 ${ }^{[39]}$ 。卢怡萌在进行中国野 生兰科植物优先保护研究时, 仅用了《中国生物多样性红色名录一高等植物卷》中的受胁迫的兰科植物作为中 国兰科植物优先保护物种 ${ }^{[40]}$ 。马琳在进行长白山森林生物多样性体系研究时, 选取了国家级、省级重点保护 
物种, 国际上较关注的物种 ( IUCN 红色名录物种、CITES 附录物种)、对生态系统或生态过程具有重要意义的 物种等, 共确定 141 种优先保护对象作为优先保护物种选择的标准 ${ }^{[41]}$ 。可见将重点保护动植物名录作为评 价指标物种,并以此作为研判生物多样性热点区域、物种多样性保护优先区已成为了研究生物多样性保护与 分布格局的重要方法之一, 只是在对于重点保护物种选择的名录范围上可能不同。本研究也采用当前这种评 价指标选择方法, 以京津冀地区自然保护区内的国家重点保护野生动植物为评价指标,共选择物种 218 种, 可 以看出在选择物种的数量上相对于以上几个研究是比较多的,也应更能代表京津冀地区的生物多样性。

（2）区域尺度上综合考虑地形地貌对物种多样性分布格局的影响更有意义。地貌单元和地形的局部变 化严重制约着光照、温度、水分甚至土壤资源的再分配 ${ }^{[42]}$ 。在大多数有关地形地貌与生物多样性分布格局的 研究中, 都是将地形地貌分解成几个单因素分别进行研究, 其中研究较多的是海拔梯度与生物多样性分布格 局的关系,其次是坡向、坡度、凹凸度等地形地貌因子与生物多样性分布格局的关系, 只有很少的研究是将地 表禇皱度, 或者是地表粗糙度等综合性的地形地貌因子作为影响因素, 开展其与生物多样性分布格局研究 的 ${ }^{[43]}$ 。然而地形地貌对生物多样性分布的影响, 尤其是植物分布的影响是综合的, 因此研究综合的地形地貌 因子对生物多样性分布的影响会更有效。

另外, 与地形有关的生物多样性的研究多是在群落或样地这样小尺度上开展的, 以群落样方数据为依据, 开展不同坡度、坡向,海拔等不同地形条件下物种多样性的变化, 如张烅、王家鸣等人开展的相关研究 ${ }^{[40,44]}$, 都是基于大样地开展的。物种多样性的空间分布格局与取样区域、取样面积、生境异质性、干扰以及生物区系 等有关 ${ }^{[45-46]}$ 。区域尺度上单位面积物种多样性的分布格局与群落尺度明显不同, “尺度效应” 在塑造物种多 样性地理分布格局中具有重要重要作用 ${ }^{[47]}$ 。因此,有研究认为仅采取小尺度样方调查, 难以反映区域的物种 多样性 ${ }^{[48]}$,Shannon 多样性均值及多样性指数也不能反映区域物种多样性全貌 ${ }^{[49-50]}$ 。因此以京津冀地区自 然保护区的平均面积这样一个中等尺度开展地形异质性与生物多样性的分布格局研究, 更有利于生物多样性 保护工作的开展。

\section{5 结论}

(1) 以国家重点保护野生动植物物种、珍稀濒危动植物种为评价指标, 评价了京津冀地区自然保护区的 物种多样性保护价值。国家级自然保护区普遍得分较高,平均得分为 204 分,比参与评分的 35 个自然保护区 平均分高出 40 分; 在省级自然保护区中也存在一些得分较高的自然保护区,如,唐海湿地自然保护区和河北 南大港自然保护区, 且得分超过了参评国家级自然保护区保护价值得分的平均值,应引起注意。不同类型自 然保护区之间的保护价值得分不存在显著差异，同一类型自然保护区的保护价值差别却很大,尤其是森林生 态系统类型自然保护区和内陆湿地类型的自然保护区。

(2) 以京津冀地区的 24 个森林类型自然保护区为参照,结合地形地貌、自然植被等因素,利用多元回归 分析方法预测了京津冀陆域范围内的生物多样性热点分布格局, 划定了三级保护优先区, 总面积为 36791.35 $\mathrm{km}^{2}$, 占京津冀总面积的 16.94\%。其中,一级保护优先区总面积为 $4611.57 \mathrm{~km}^{2}$, 占总优先区域面积的 $12.53 \%$; 二级保护优先区总面积为 $16045.79 \mathrm{~km}^{2}$, 占总优先区域面积的 $43.61 \%$; 三级保护优先区总面积为 16133.98 $\mathrm{km}^{2}$, 占总优先区域面积的 $43.85 \%$ 。

\section{参考文献 (References) :}

[ 1 ] 马克平. 中国生物多样性热点地区 (Hotspot) 评估与优先保护重点的确定应该重视. 植物生态学报, 2001, 25(1): 125, $124-124$.

[ 2 ] 李迪强, 林英华, 陆军. 尤溪县生物多样性保护优先地区分析. 生态学报, 2002, 22( 8): 1315-1322.

[ 3 ] 高玉平. 上海市物种多样性优先保护地与郊野公园体系构建研究 $[\mathrm{D}]$. 上海: 华东师范大学, 2007.

[ 4 ] 徐卫华, 欧阳志云, 黄璜, 等. 中国陆地优先保护生态系统分析. 生态学报, 2006, 26(1): 271-280.

[ 5 ] Barthlott W, Hostert A, Kier G, Küper W, Kreft H, Mutke J, Rafiqpoor D, Sommer Jan H. Geographic patterns of vascular plant diversity at continental to global scales. Erdkunde, 2007, 61(4): 305-315.

[ 6 ] Barthlott W, Mutke J, Rafiqpoor D, Kier G, Kreft H. Global centers of vascular plant diversity. Nova Acta Leopoldina, 2005, 92(342): 61-83.

[ 7 ] Antonelli A, Kissling W D, Flantua S G A, Bermúdez M A, Mulch A, Muellner-Riehl A N, Kreft H, Linder H P, Badgley C, Fjeldså J, Fritz S 
A, Rahbek C, Herman F, Hooghiemstra H, Hoorn C. Geological and climatic influences on mountain biodiversity. Nature Geoscience, 2018, 11 (10) : 718-725.

[ 8 ] Badgley C, Smiley T M, Terry R, Davis E B, DeSantis L R G, Fox D L, Hopkins S S B, Jezkova T, Matocq M D, Matzke N, McGuire J L, Mulch A, Riddle B R, Roth V L, Samuels J X, Strömberg C A E, Yanites B J. Biodiversity and topographic complexity : modern and geohistorical perspectives. Trends in Ecology \& Evolution, 2017, 32(3): 211-226.

[9] 田瑞云, 王玉宽, 傅斌, 刘援. 基于 Dem 的地形单元多样性指数及其算法. 地理科学进展, 2013, 32(1)：121-129.

[10] 李巧燕, 王襄平. 长江三峡库区物种多样性的垂直分布格局: 气候、几何限制、面积及地形异质性的影响. 生物多样性, 2013, 21 (2): $141-152$.

[11] 袁铁象, 张合平，欧芷阳，谭一波. 地形对桂西南喀斯特山地森林地表植物多样性及分布格局的影响. 应用生态学报, 2014, 25(10)： 2803-2810.

[12] 么旭阳, 胡耀升, 刘艳红. 长白山阔叶红松林典型森林群落功能多样性及其与地形因子的关系. 西北农林科技大学学报: 自然科学版, 2014, 42(10): 95-102.

[13］国务院. 中共中央、国务院印发《国家新型城镇化规划(2014-2020 年)》(2014 年第 9 号). (2014-03-16). http://www.gov.cn/gongbao/ content/2014/content_2644805.htm.

[14] 国务院. 中共中央、国务院印发《生态文明体制改革总体方案》. (2015-09-21). http://www.gov. cn/guowuyuan/2015-09/21/content_ 2936327.htm.

[15] 邢珊. 京津冀区域经济差异及影响因素研究 [D]. 秦皇岛: 燕山大学, 2013.

[16] 张碟. 基于地形起伏度的地貌形态划分研究——以京津冀地区为例 [D]. 石家庄: 河北师范大学, 2009.

[17] 李霄宇, 白庆红, 张岩, 邢韶华, 崔国发. 河北省自然保护区体系建设分析. 林业资源管理, 2010, (1) : 93-101.

[18］崔国发, 邢韶华. 北京喇叭沟门自然保护区综合科学考察报告. 北京: 中国林业出版社, 2009.

[19] 邢韶华, 鲍伟东, 王清春, 崔国发. 北京市雾灵山自然保护区综合科学考察报告. 北京: 中国林业出版社, 2013.

[20] 邢韶华, 武占军, 王楠. 河北大海陀国家级自然保护区综合科学考察报告. 北京: 中国林业出版社, 2017.

[21] 奕晓峰, 李迪强, 李广良. 北京云峰山自然保护区生物多样性及保护研究. 北京: 中国大地出版社, 2011.

[22] 赵建成, 吴跃峰, 李盼威. 温带暖温带交接带生物多样性研究. 北京: 科学出版社, 2005.

[23] 赵建成, 吴跃峰, 刘宝忠. 河北辽河源自然保护区生物多样性及其保护. 北京: 科学出版社, 2007.

[24] 赵建成, 吴跃峰, 关文兰. 河北驼梁自然保护区科学考察与生物多样性研究. 北京: 科学出版社, 2008.

[25] 侯建华, 聂鸿飞. 河北塞罕坝国家级自然保护区综合科学考察报告. 河北: 河北科学技术出版社, 2015.

[26] 于广琳, 汪苏燕, 马春, 张光玉. 天津古海岸与湿地国家级自然保护区综合科学考察报告集. 北京: 化学工业出版社, 2013.

[27] 李惠欣. 河北衡水湖自然保护区种子植物区系初步研究 [D]. 石家庄: 河北师范大学, 2007.

[28] 陈维川. 北京蒲洼自然保护区植物多样性及其保护研究 [D]. 北京: 北京林业大学, 2005.

[29] 王天罡. 天津八仙山自然保护区植物多样性及其保护研究 [D]. 北京: 北京林业大学, 2007.

[30］崔国发，邢韶华，赵勃. 北京山地植物和植被保护研究. 北京: 中国林业出版社, 2008.

[31] 吴跃峰, 徐成立, 孔昭普. 河北滦河上游国家级自然保护区脊椎动物志. 北京: 科学出版社, 2013.

[32] 赵建成, 郭书涁, 李盼威. 小五台山植物志 (上下卷). 北京: 科学出版社, 2011.

[33] 李春秋. 小五台山自然保护区陆生脊椎动物研究. 北京: 中国科学技术出版社, 1996.

[34] 中国科学院中国植被图编委员会. 1:1000000 中国植被图集. 北京: 科学出版社, 2001.

[35] 总参谋部测绘导航局. 中华人民共和国地图集. 北京: 星球地图出版社, 2014.

[36] 北京林业大学. LY/T 2649-2016 自然保护区生物多样性保护价值评估技术规程. 北京: 中国标准出版社, 2016.

[37] 郭子良, 邢韶华, 崔国发. 自然保护区物种多样性保护价值评价方法. 生物多样性, 2017, 25(3): 312-324.

[38］柇简, 彭杨靖, 邢韶华, 崔国发. 我国东北三省自然保护区物种保护价值评估. 生态学报, 2018，38(18)：6473-6483.

[39] 栾晓峰, 黄维妮, 王秀否, 刘敏超, 刘世荣, 吴波, 李迪强. 基于系统保护规划方法东北生物多样性热点地区和保护空缺分析. 生态学 报, 2009, 29(1): 144-150.

[40］卢怡萌. 基于系统保护规划的中国野生兰科植物的优先保护研究 [D]. 太原: 山西大学, 2014.

[41] 马琳. 长白山地区森林生物多样性保护体系研究 [D]. 北京: 北京林业大学, 2015.

[42] 张篮, 熊高明, 陈志刚, 焚大勇, 谢宗强. 神农架米心水青冈-曼青冈群落的地形异质性及其生态影响. 生态学报, 2004, 24(12): 2686-2692.

[43] 王艳霞, 丁琨, 周汝良. 基于地形、水热指标的陆地生物多样性富集度评估一一以云南为例. 云南大学学报：自然科学版, 2017, 39(3) : 481-493.

[44] 王家鸣, 许涵, 李意德, 林明献, 周璋, 骆土寿, 陈德祥. 地形异质性对尖峰岭热带山地雨林木本植物群落结构及多样性的影响. 林业科 学, 2018, 54(1): 1-11.

[45] Wang Z G, Ye W H, Cao H L, Lian J Y. Spatial distribution of species diversity indices in a monsoon evergreen broadleaved forest at Dinghushan Mountain. Biodiversity Science, 2008, 16(5): 454-461.

[46] 朱道光, 柴春荣, 李金博, 崔福星, 曾昭文, 王继丰, 倪红伟. 物种多样性与空间尺度的关系研究进展. 国土与自然资源研究, 2014, (5) : 95-96.

[47] 冯建孟, 徐成东. 云南西部地区地带性植物群落物种多样性的地理分布格局. 生态学杂志, 2009, 28(4): 595-600.

[48] Hendrickx F, Maelfait J P, Van Wingerden W, Schweiger O, Speelmans M, Aviron S, Augenstein I, Billeter R, Bailey D, Bukacek R, Burel F, Diekötter T, Dirksen J, Herzog F, Liira J, Roubalova M, Vandomme V, Bugter R. How landscape structure, land-use intensity and habitat diversity affect components of total arthropod diversity in agricultural landscapes. Journal of Applied Ecology, 2007, 44(2) : 340-351.

[49] Villalobos F, Lira-Noriega A, Soberón J, Arita H T. Range-diversity plots for conservation assessments: using richness and rarity in priority setting. Biological Conservation, 2013, 158: 313-320

[50］彭羽, 卿凤婷, 米凯, 薛达元. 生物多样性不同层次尺度效应及其耦合关系研究进展. 生态学报, 2015, 35(2): 577-583. 